\title{
Identification of Parental Genome Construction and Inherited Morphological Characteristics in Triploid and AneuploidIntergeneric Hybrids from a Diploid-Diploid Cross between Citrus and Fortunella
}

\author{
Kiichi Yasuda ${ }^{1,+}$, Masaki Yahata ${ }^{2,+}$, Mai Sato ${ }^{1}$, Miki Sudo ${ }^{2}$, Akiyoshi Tominaga ${ }^{2}$ and Hisato Kunitake ${ }^{3, * \mathbb{D}}$ \\ 1 School of Agriculture, Tokai University, 9-1-1 Toroku, Higashi-ku, Kumamoto-shi, \\ Kumamoto 862-8652, Japan; yk964422@tsc.u-tokai.ac.jp (K.Y.); sm098295@hope.tokai-u.jp (M.S.) \\ 2 Faculty of Agriculture, Shizuoka University, 836 Ohya, Suruga, Shizuoka 422-8529, Japan; \\ yahata.masaki@shizuoka.ac.jp (M.Y.); sudo.miki@shizuoka.ac.jp (M.S.); \\ tominaga.akiyoshi@shizuoka.ac.jp (A.T.) \\ 3 Faculty of Agriculture, University of Miyazaki, 1-1 Gakuenkibanadainishi, Miyazaki-shi, \\ Miyazaki 889-2192, Japan \\ * Correspondence: hkuni@cc.miyazaki-u.ac.jp; Tel.: +81-985-587-166 \\ + These authors contributed equally to the article.
}

Citation: Yasuda, K.; Yahata, M.; Sato, M.; Sudo, M.; Tominaga, A.; Kunitake, H. Identification of Parental Genome Construction and Inherited Morphological Characteristics in Triploid and AneuploidIntergeneric Hybrids from a Diploid-Diploid Cross between Citrus and Fortunella. Agronomy 2021, 11, 1988. https:// doi.org/10.3390/agronomy11101988

Academic Editors:

Małgorzata Podwyszyńska and Anna Trojak-Goluch

Received: 30 July 2021

Accepted: 25 September 2021

Published: 30 September 2021

Publisher's Note: MDPI stays neutral with regard to jurisdictional claims in published maps and institutional affiliations.

Copyright: () 2021 by the authors. Licensee MDPI, Basel, Switzerland. This article is an open access article distributed under the terms and conditions of the Creative Commons Attribution (CC BY) license (https:// creativecommons.org/licenses/by/ $4.0 /)$.
Abstract: We previously obtained two intergeneric hybrids with different ploidies, i.e., aneuploid $(2 \mathrm{n}=28)$ and eutriploid, from diploid-diploid crosses between 'Kiyomi' tangor (Citrus unshiu Marcow. $\times$ C. sinensis (L.) Osbeck) and Meiwa kumquat (Fortunella crassifolia Swingle) as novel breeding materials for a seedless kumquat. In this study, we attempted to clarify the construction of the parental genomes of these hybrids by SSR genotyping and genomic in situ hybridization (GISH) - chromomycin A3 (CMA) analysis. SSR genotyping in NSX43 (LG5) and CiBE2227 (LG8) loci revealed that both hybrids inherited one allele from 'Kiyomi' tangor and two heterozygous alleles from Meiwa kumquat. The GISH analysis failed due to the high genomic homology between Citrus and Fortunella. At the same time, the CMA karyotype compositions of the two intergeneric hybrids (H15-701: $2 \mathrm{~A}+1 \mathrm{~B}+3 \mathrm{C}+13 \mathrm{D}+7 \mathrm{E}+1 \mathrm{~F}+1 \mathrm{Dst} ; \mathrm{H} 15-702: 3 \mathrm{~A}+1 \mathrm{~B}+2 \mathrm{C}+15 \mathrm{D}+4 \mathrm{E}+1 \mathrm{~F}$ $+1 \mathrm{Dst}$ ) and both parents ('Kiyomi' tangor: $1 \mathrm{~A}+2 \mathrm{~B}+2 \mathrm{C}+6 \mathrm{D}+7 \mathrm{E}$; Meiwa kumquat: $2 \mathrm{~A}+2 \mathrm{C}+$ $12 \mathrm{D}+1 \mathrm{~F}+1 \mathrm{Dst})$ were completely revealed. We identified the parental genome construction and polyploidization processes in both intergeneric hybrids on the basis of these SSR genotypes and CMA karyotype compositions according to the following theory: the SSR genotypes and chromosome compositions were the same as those of the somatic chromosome and two-fold after the first division (even number) in unreduced gametes caused by first-division restitution (FDR) and second-division restitution (SDR), respectively. Consequently, we determined that both intergeneric hybrids may have had two genomes derived from the $2 \mathrm{n}$ male unreduced gamete as a result of the FDR of the Meiwa kumquat. In addition, most horticultural traits of the leaves, flowers, and fruits of both hybrids showed intermediate traits of the parents, but the fruit sizes and flowering habits were more like those of the two inherited genomes of Meiwa kumquat.

Keywords: CMA karyotype; first-division restitution (FDR); genome construction; SSR marker; unreduced gamete

\section{Introduction}

The kumquat (Fortunella) is closely related to Citrus and Poncirus in the subfamily Aurantioideae (Citroideae) of the family Rutaceae [1]. In Japan, the Meiwa kumquat (F. crassifolia Swingle) is eaten mainly in raw form or processed as candied fruit, jam, or marmalade. For this species, achieving seedlessness is one of the most important goals, because the relatively large seeds in the bite-size fruits are a major impediment to the 
eating and processing of the fruit. Nevertheless, only two varieties of kumquat have been registered as seedless or as having few seeds under the Plant Variety Protection and Seed Act in Japan (Ministry of Agriculture, Forestry and Fisheries, http/ / www.hinsyu2.maff. go.jp, 15 July 2021): 'Puchimaru' (registration no. 10379) and 'Yumemaru' (registration no. 19999). In our previous study, which aimed to produce novel breeding materials for seedless kumquats, we selected two superior seedlings of Meiwa kumquats as the pollen parents from among seedlings obtained from diploid-diploid crosses between 'Kiyomi' tangor (C. unshiu Marcow. $\times$ C. sinensis (L.) Osbeck) and six Fortunella species. On the basis of genome size and DNA analyses, we confirmed that the seedlings were aneuploid $(2 n=28)$ and eutriploid $(2 n=3 x=27)$ intergeneric hybrids [2].

Many reports have found that, as in our result, triploid plants were generated by diploid-diploid sexual crosses [3-9]. The polyploidization of the progenies had to be a consequence of $2 \mathrm{n}$ unreduced gamete formation. As a result, these triploid plants should have had a genome construction with a 1:2 ratio, one reduced gamete and the other unreduced gamete, respectively. The major mechanisms underlying $2 \mathrm{n}$ gamete formation in plants are first-division restitution (FDR) and second-division restitution (SDR) resulting from the failure of the first or second meiotic division, respectively [10,11]. The first and second divisions show different chromosome segregation patterns, so FDR and SDR result in different chromosomal modes of inheritance. Several clarifications of sexual polyploidization through meiotic restitution in citrus have been attempted using genetic markers and cytological analyses [12-16].

The simple sequence repeat (SSR) is an effective molecular maker for genetic and phylogenetic studies in many plants because of its polymorphism and co-dominant expression. Genotyping with this molecular marker is a powerful tool for identifying parental genome construction in sexual polyploidization seedlings of citrus and for clarifying their meiotic restitution mechanism [12-15]. Chen et al. [12] reported that the triploid citrange hybrids obtained from diploid-diploid crosses between sweet orange (C. sinensis) and trifoliate orange (Poncirus trifoliata (L.) Raf.) originated in $2 \mathrm{n}$ female unreduced gametes resulting from FDR instead of SDR, according to the SSR genotypes. If the position of the SSR locus on the genetic linkage map is known, the genotyping provides more detailed information such as partial chromosomal recombination.

The fluorochrome chromomycin A3 (CMA), a guanine-cytosine (GC) base-specific fluorochrome, banding technique is comparatively simple and the most popular karyotype analysis in citrus. Thus, the karyotypes based on CMA banding patterns have provided important information for many taxonomic and polyploidy breeding studies in citrus and kumquat [17-24]. Yang et al. [16] considered the participation of male or female unreduced gametes in both triploid and tetraploid seedlings obtained from the diploid-diploid cross between 'Tosa-Buntan' (Citrus maxima (Burm.) Merr.) and 'Suisho-Buntan' using CMA karyotype compositions. Genomic in situ hybridization (GISH) using parental genomic DNA as a probe is a powerful tool for identifying the parental genomes in hybrid polyploids, hybrid plants, and partial allopolyploids [25]. In Aurantioideae, including citrus plants, the identification of the parental genome with GISH has also been successful in an intergeneric somatic hybrid combining sour orange (C. aurantium L.) and trifoliate orange (Poncirus trifoliata (L.) Raf.) [26] and in a sexual intergeneric hybrid between a tangor cultivar (Citrus spp.) and Citropsis schweinfurthii (Engl.) Swing and M. Kell. [27]. Yasuda et al. [27] additionally revealed CMA karyotype compositions of male and female gametes in this intergeneric hybrid by GISH and CMA double staining (GISH-CMA) analysis. Studies on $2 \mathrm{n}$ unreduced gamete formation and the mechanism used by GISH in Liliaceae have been reported [28-30], although there are no similar reports with these in Aurantioideae.

In this report, we further performed SSR genotyping and CMA-GISH analysis in order to clarify the parental genome construction in two aneuploid and triploid intergeneric hybrids and the origin of unexpected $2 n$ unreduced gametes through either FDR or SDR in the diploid-diploid cross between Citrus and Fortunella as genetic fundamental informa- 
tion for polyploidy breeding. In addition, the morphological characteristics and fruit traits of these hybrids and both parents were compared and investigated to clarify the effect of parental genome construction on the inherited traits.

\section{Materials and Methods}

\subsection{Plant Materials}

Two intergeneric hybrids, H15-701 $(2 n=28)$ and H15-702 $(2 n=3 x=27)$, and their parents ( $2 n=2 x=18)$, 'Kiyomi' tangor (seed parent) and Meiwa kumquat (pollen parent), were used for our study. They were grafted onto trifoliate orange and cultivated at the Kibana Agriculture Science Station of the University of Miyazaki, Japan.

\subsection{SSR Genotyping}

Total DNA was extracted from young leaves of each plant following the method described by Doyle and Doyle [31] with some modifications. The isolated gDNA was diluted to $5 \mathrm{ng} \mu \mathrm{L}^{-1}$ with TE buffer and stored at $4{ }^{\circ} \mathrm{C}$ for SSR analysis. Twenty SSR markers distributed across all linkage groups (LGs) designed by Ollitraut et al. [32,33] or Shimizu et al. [34] were used in the present study (Table S1). PCR amplifications were performed using a Biometra TAdvanced Thermocycler 96G (Analytik Jena, Jena, Germany) in $10 \mu \mathrm{L}$ final volume containing $0.5 \mathrm{ng} \mu \mathrm{L}^{-1} \mathrm{gDNA}, 0.2 \mu \mathrm{M}$ forward and reverse primers, and $5 \mu \mathrm{L}$ GoTaq Green Master Mix (Promega, Madison, WI, USA). The PCR protocol was as follows: denaturation at $94{ }^{\circ} \mathrm{C}$ for $3 \mathrm{~min}$ followed by $30-35$ cycles of $30 \mathrm{~s}$ at $94{ }^{\circ} \mathrm{C}$, $35 \mathrm{~s}$ at annealing temperature for each primer shown in Table S1, and $35 \mathrm{~s}$ at $72{ }^{\circ} \mathrm{C}$. Polyacrylamide gel electrophoresis (PAGE) of PCR-amplified products was carried out on a $15 \%$ polyacrylamide gel at $300 \mathrm{~V}$ for $55 \mathrm{~min}$. These gels were stained with TBE buffer containing $0.1 \mu \mathrm{g} \mathrm{mL}^{-1}$ ethidium bromide for $30 \mathrm{~min}$, and then were visualized under UV irradiation.

\subsection{GISH-CMA Analysis}

Young leaves (approximately 3-5 $\mathrm{mm}$ long) were excised from each plant, immersed in $2 \mathrm{mM}$ 8-hydroxyquinoline for $8-10 \mathrm{~h}$ at $4{ }^{\circ} \mathrm{C}$, and fixed in a mixed solution of ethanol and acetic acid (3:1) at $4{ }^{\circ} \mathrm{C}$ until the leaf color was quite bleached. Enzymatic maceration and air-drying were performed according to the method of Fukui [35] and Yahata et al. [36]. The young leaves were washed in distilled water to remove the fixative and then macerated in an enzyme mixture containing 2.0\% $(w / v)$ Cellulase Onozuka RS (Yakult Pharmaceutical Industries, Tokyo, Japan), 1.0\% (w/v) Macerozyme (MP Biomedicals, Solon, OH, USA), $0.3 \%$ pectolyase Y-23 ( $w / v)$ (Kyowa Chemical Products, Osaka, Japan) and $200 \mathrm{mM}$ EDTA at $37^{\circ} \mathrm{C}$ for $40 \mathrm{~min}$. The chromosomes were stained with $2.0 \%$ Giemsa solution (Merck, Darmstadt, Germany) in $1 / 30$ phosphate buffer ( $\mathrm{pH}$ 6.8) for 30 min. They were then rinsed with distilled water, air dried, and observed under an optical microscope. After the numbers and positions of the chromosomes on the slide were confirmed, the chromosomes were de-stained with 70\% methanol and GISH-CMA analysis was performed.

Chromosome preparations were performed following the methods described above. GISH-CMA analysis was conducted as described by Yasuda et al. [27]. The total genomic DNA of 'Kiyomi' tangor was extracted from young leaves according to the modified method of Doyle and Doyle [31], labeled with biotin-16-dUTP using the Nick Translation Kit (Roche Diagnostics, Rotkreuz, Switzerland), and used as the probe DNA. Excess unlabeled genomic DNA of Meiwa kumquat was used as the blocking DNA. A $100 \mu \mathrm{L}$ sample of the hybridization mixture contained $1 \mu \mathrm{g}$ probe DNA and $20 \mu \mathrm{g}$ blocking DNA. After hybridization, probe hybridization signals were amplified with fluorescein avidin DN (Vector Laboratories, Burlingame, CA, USA) fluorescein-isothiocyanate (FITC) conjugate and counterstained with propidium iodide (PI). The preparations were mounted with VECTASHIELD mounting medium (Vector Laboratories, Burlingame, CA, USA) and observed under a BX51 fluorescence microscope (Olympus, Tokyo, Japan). The preparations used for GISH analysis were de-stained with a mixed solution of ethanol and acetic acid (3:1) and $100 \%$ methanol, and air-dried. They were subsequently stained with $0.1 \mathrm{mg} \mathrm{L}^{-1} \mathrm{CMA}$ and 
$0.1 \mathrm{mg} \mathrm{L}^{-1}$ Distamycin A hydrochloride (Sigma-Aldrich, Steinheim, Germany) following the modified method described by Befu et al. [17] and observed under a fluorescence microscope. At least 3 cells were observed for each sample to reveal karyotype.

\subsection{Identification of Parental Genome Construction}

Based on the CMA karyotype compositions of two intergeneric hybrids and their parents, the inherited parental genomes were estimated according to the theory described by Yang et al. [16]. It was expected that, if FDR caused unreduced gamete formation, aneuploidy- or triploid hybrids had almost the same karyotype compositions with somatic chromosomes in either the male or female parent (Figure 1). On the other hand, an even number of karyotypes $(2 \times$ karyotype compositions after the first division) had to be inherited as an unreduced gamete to the hybrids from the parent on the occurrence of SDR.

SSR genotypes provide useful information for the identification of the parental genome only if the genotype specific to each parent is heterozygous. As in the theory of cytological analysis above, if SDR caused unreduced gamete formation, triploid and triploid-like aneuploidy hybrids should inherit one genotype from each parent. On the other hand, if the polyploidization in hybrids is caused by FDR, both hetero-genotypes should be inherited from the parent that formed the unreduced gamete.

Consequently, we attempted to clarify the process of generating unreduced gametes and the genome construction of the parents of the hybrids in accord with these results in both molecular marker and cytological analyses.



Figure 1. The process of the $2 \mathrm{n}$ unreduced gamete formation through two abnormal divisions, FDR and SDR, and the expected chromosome compositions of the $2 n$ unreduced gamete.

\subsection{Pollen Size Measurement}

Ten pollen grains each of diploid and tetraploid Meiwa kumquat were measured on a microscope after staining with acetocarmine solution (Nacalai tesque, Kyoto, Japan) followed by the crushing of a nearly mature anther. Incidentally, the tetraploid Meiwa kumquat was an autotetraploid derived from nucellar embryos [37] and cultivated at the Center for Education and Research of Field Science of Shizuoka University. 


\subsection{Morphological Characteristics and Fruit Traits}

The characteristics of fully expanded leaves were measured (e.g., leaf blade size, petiole wing size, guard cell size, and stomatal density), flowers just before bloom (e.g., the sizes of flower buds, petals, pistils, and ovaries), and fruits (e.g., fruit weight, fruit size, pericarp thickness, the number of seeds and the soluble solid content). Each measurement used 20 samples ( 50 samples were investigated on only the number of embryos per seed).

\section{Results}

\subsection{SSR Genotyping}

The clearly separated bands available for SSR genotyping on polyacrylamide gel were detected in 11 (LG1-6, 8, and 9) of the 18 SSR loci (Table 1). 'Kiyomi' tangor and Meiwa kumquat each had one or two alleles, while each intergeneric hybrid inherited one to three parental alleles, except that an allele nonspecific to both parents was detected in SSR08B62. The detected alleles in NSX43 (LG5) and CiBE2227 (LG8) were especially useful because they were completely different from the parents and heterozygous in at least one parent (Figure 2). H15-701 and H15-702 inherited one of the alleles of 'Kiyomi' tangor and both of the alleles of Meiwa kumquat in these loci.

Table 1. SSR genotyping of 'Kiyomi' tangor, Meiwa kumquat, and their intergeneric hybrids.

\begin{tabular}{cccccc}
\hline Locus & Linkage Group & 'Kiyomi' Tangor & H15-701 & H15-702 & Meiwa Kumquat \\
\hline NSX175 & 1 & $180 / 214$ & $180 / 200 /(200)^{2}$ & $180 / 200 /(200)$ & $200 / 200$ \\
TSGR265 & 2 & $150 / 180$ & $150 /(150) / 180$ & $150 /(150) /(150)$ & $150 / 150$ \\
TSR8EM24 & 3 & $136 / 146$ & $136 / 156 /(156)$ & $146 / 156 /(156)$ & $156 / 156$ \\
TSRA110 & 4 & $135 / 145$ & $135 / 160 /(160)$ & $145 / 160 /(160)$ & $160 / 160$ \\
NSX43 ${ }^{1}$ & 5 & $110 / 158$ & $130 / 135 / 158$ & $110 / 130 / 135$ & $130 / 135$ \\
SSR08B62 $^{2}$ & 5 & $262 / 274$ & $(262) /(262) / 274+$ Alpha & $(262) /(262) / 274+$ Alpha & $262 / 262$ \\
NSX169 & 5 & $140 / 160$ & $135 /(135) / 160$ & $135 /(135) / 140$ & $135 / 135$ \\
GSR5114 & 5 & $300 / 310$ & $303 /(303) / 310$ & $303 /(303) / 300$ & $280 / 280$ \\
CiBE2227 1 & 8 & $155 / 155$ & $155 / 160 / 165$ & $155 / 160 / 165$ & $160 / 165$ \\
GSR3141 & 8 & $104 / 104$ & $104 /$ n.d. ${ }^{3}$ & $104 /$ n.d. & n.d. \\
NSX141 & 9 & $280 / 298$ & $280 /(280) / 280+$ Alpha & $280 /(280) / 280+$ Alpha & $280 / 280+$ Alpha \\
\hline
\end{tabular}

${ }^{1}$ The loci shown in Figure 2 were especially useful genotypes; ${ }^{2}$ Numbers in parentheses indicate the estimated bands derived from Meiwa kumquat; ${ }^{3}$ n.d. means not detected.

\subsection{GISH and CMA Karyotype Compositions}

First, GISH analysis, the most dominant tool for identifying the parental genome construction in a hybrid, was performed on the chromosomes of two intergeneric hybrids. The green signal (FITC) using the biotin-labeled 'Kiyomi' tangor DNA probe was detected on all of the 27 or 28 chromosomes of each hybrid (data not shown). Moreover, we had the same disappointing results in an additional examination in which we changed the probe DNA: the blocking DNA ratios to 1:50 and 1:100.

Subsequently, these chromosomes were de-stained and used for CMA analysis with the chromosomes of the parents. The chromosomes were classified into the following seven types based on the numbers and positions of CMA banding patterns according to Yamamoto and Tominaga [38] and Yamamoto et al. [22]: $\mathrm{A}=2$ telomeric bands and 1 proximal band; $\mathrm{B}=1$ telomeric and 1 proximal band; $\mathrm{C}=2$ telomeric bands; $\mathrm{D}=1$ telomeric band; $\mathrm{E}=$ no bands; $\mathrm{F}=1$ proximal band; and Dst $=$ type $\mathrm{D}$ with a satellite chromosome (Figure 3). The CMA karyotype compositions of the parents were $1 \mathrm{~A}+2 \mathrm{~B}+2 \mathrm{C}+6 \mathrm{D}+7 \mathrm{E}$ in 'Kiyomi' tangor and $2 \mathrm{~A}+2 \mathrm{C}+12 \mathrm{D}+1 \mathrm{~F}+1 \mathrm{Dst}$ in Meiwa kumquat (Table 2, Figure 4a,d). Types B and E chromosomes specifically existed in 'Kiyomi' tangor, while types F and Dst chromosomes were observed only in Meiwa kumquat. Furthermore, the aneuploid (H15-701) and triploid (H15-702) hybrids showed the karyotype compositions including all types of $2 \mathrm{~A}+1 \mathrm{~B}+3 \mathrm{C}+13 \mathrm{D}+7 \mathrm{E}+1 \mathrm{~F}+1 \mathrm{Dst}$ and $3 \mathrm{~A}+1 \mathrm{~B}+2 \mathrm{C}+15 \mathrm{D}+4 \mathrm{E}+1 \mathrm{~F}+$ 1Dst (Figure $4 b, c$ ). 


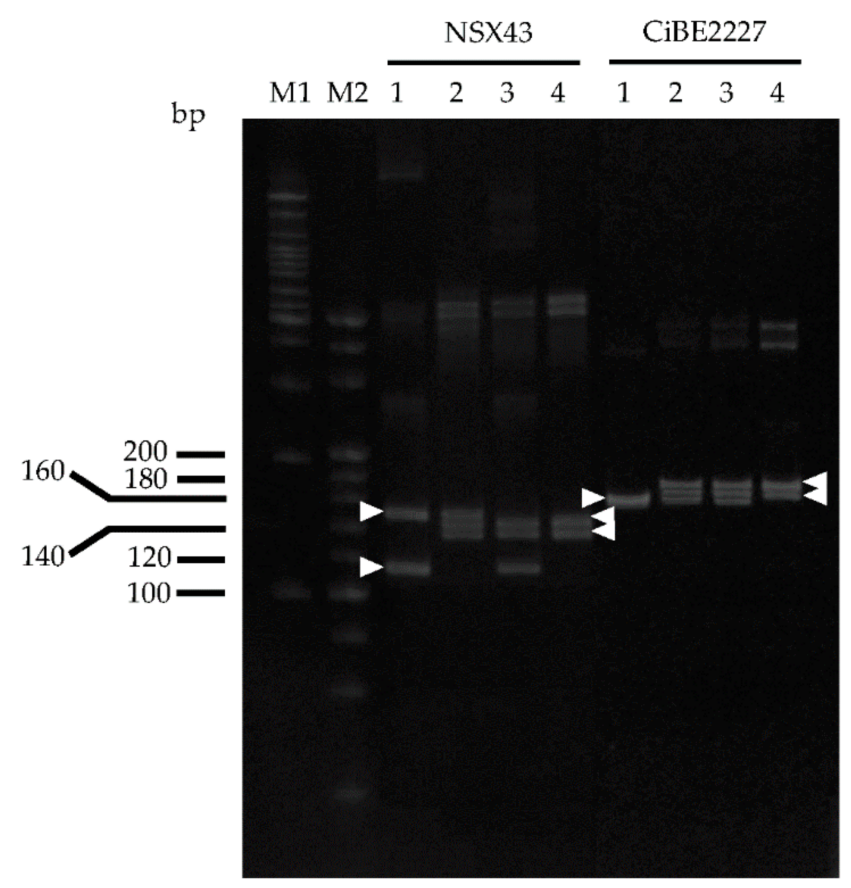

Figure 2. SSR analysis of 'Kiyomi' tongor, Meiwa kumquat, and their hybrids with PAGE in NSX43 (LG5) and CiBE2227 (LG8) loci. Arrowheads indicate the bands specific to each parent. M1: 100 bp ladder marker, M2: 20 bp ladder marker, 1: 'Kiyomi’ tongor, 2: H15-701, 3: H15-702, 4: Meiwa kumquat.

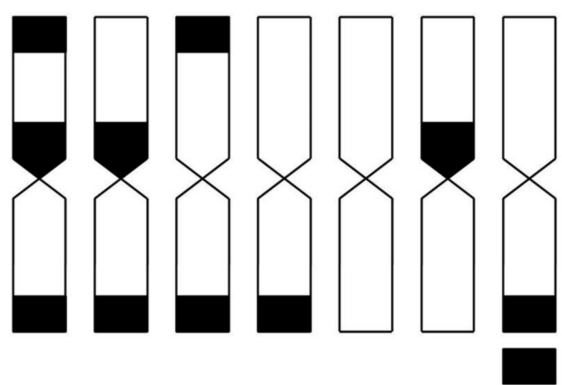

\section{$\begin{array}{lllllll}\text { A } & \text { B } & \text { C } & \text { D } & \text { E } & \text { F } & \text { Dst }\end{array}$}

Figure 3. Idiograms of CMA banding patterns according to Yamamoto and Tominaga (2003) and Yamamoto et al. (2007). A = two telomeric bands and one proximal band, B = one telomeric and one proximal band, $\mathrm{C}=$ two telomeric bands, $\mathrm{D}=$ one telomeric band, $\mathrm{E}=$ no band, $\mathrm{F}=$ one proximal band, and Dst = type D with a satellite chromosome.

Table 2. CMA karyotype compositions of 'Kiyomi' tangor, Meiwa kumquat, and their hybrids.

\begin{tabular}{|c|c|c|c|}
\hline \multicolumn{2}{|l|}{ Strain } & Ploidy & CMA Karyotype Composition \\
\hline \multicolumn{2}{|c|}{ ‘Kiyomi' tangor } & $2 n=2 x=18$ & $1 A+2 B+2 C+6 D+7 E$ \\
\hline \multirow{2}{*}{$\begin{array}{l}\text { 'Kiyomi' tangor } \times \\
\text { Meiwa kumquat }\end{array}$} & H15-701 & $\begin{array}{c}\text { aneuploid } \\
2 n=28\end{array}$ & $2 \mathrm{~A}+1 \mathrm{~B}+3 \mathrm{C}+13 \mathrm{D}+7 \mathrm{E}+1 \mathrm{~F}+1 \mathrm{Dst}$ \\
\hline & $\mathrm{H} 15-702$ & $2 n=3 x=27$ & $3 \mathrm{~A}+1 \mathrm{~B}+2 \mathrm{C}+15 \mathrm{D}+4 \mathrm{E}+1 \mathrm{~F}+1 \mathrm{Dst}$ \\
\hline \multicolumn{2}{|c|}{ Meiwa kumquat } & $2 n=2 x=18$ & $2 \mathrm{~A}+2 \mathrm{C}+12 \mathrm{D}+1 \mathrm{~F}+1 \mathrm{Dst}$ \\
\hline
\end{tabular}



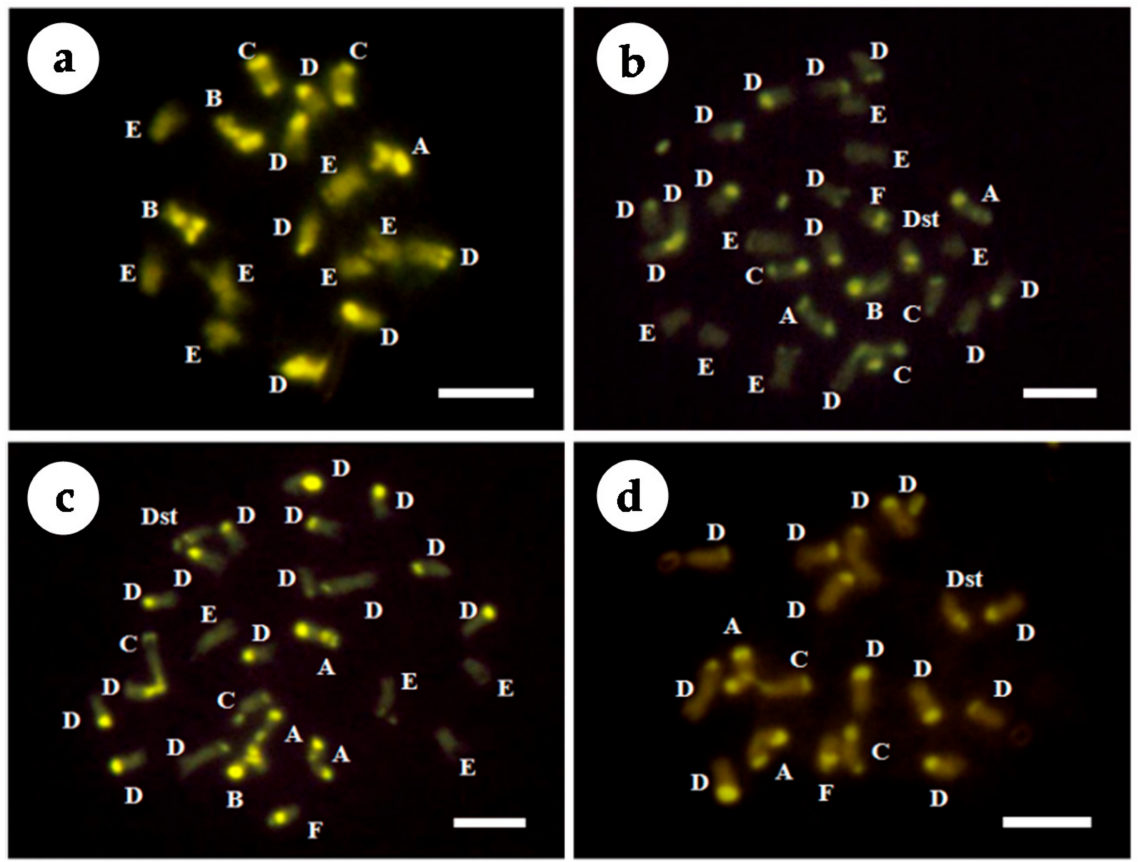

Figure 4. CMA staining of the somatic chromosomes at metaphase in young leaves of 'Kiyomi' tangor, Meiwa kumquat, and their hybrids. (a) 'Kiyomi' tangor ( $2 \mathrm{n}=2 \mathrm{x}=18)$, (b) H15-701 (2n = 28), (c) H15$702(2 n=3 x=27)$, (d) Meiwa kumquat $(2 n=2 x=18) . A=$ two telomeric bands and one proximal band, $\mathrm{B}=$ one telomeric and one proximal band, $\mathrm{C}=$ two telomeric bands, $\mathrm{D}=$ one telomeric band, $\mathrm{E}=$ no band, $\mathrm{F}=$ one proximal band, and Dst $=$ type $\mathrm{D}$ with a satellite chromosome. Bar represents $5.0 \mu \mathrm{m}$ for all figures.

\subsection{Identification of Parental Genome Construction}

Figure 5 shows the SSR genotypes of the parents, the segregation of both intergeneric hybrids, and the expected alleles of gamete formation in NSX43 and CiBE2227 loci. Each hybrid had two heterozygous alleles of Meiwa kumquat and one of 'Kiyomi' tangor, suggesting that these were derived from the zygosis of two gametes: the reduced female gamete and the unreduced male gamete through FDR. If polyploidizations were caused by SDR, two bands, one of which was a homozygous band of unreduced gametes, should be detected in triploid and triploid-like aneuploid hybrids. Additionally, this hypothesis was supported by other loci with the same alleles between parents (Table 1).

We confirmed the genome construction derived from the parents of two intergeneric hybrids at the chromosomal level, based on CMA karyotype compositions using the theory described above (Figure 6). First, the karyotype composition of H15-701 had odd-numbered $1 \mathrm{~B}, 7 \mathrm{E}, 1 \mathrm{~F}$, and 1Dst specific types of each parent, suggesting that this hybrid did not include the chromosomes of male or female unreduced gamete by SDR. In the same way, the types B, F, and Dst chromosomes were also odd numbered in the karyotype compositions of H15-702. Second, there were fewer type B and/or E chromosomes in the karyotype compositions of both hybrids together compared to those in 'Kiyomi' tangor, indicating that the polyploidization of these hybrids was not associated with the female unreduced gamete by FDR. Based on these results and a process of elimination, H15-702 consisted of the $2 \mathrm{n}$ male unreduced gamete by FDR with $2 \mathrm{~A}+2 \mathrm{C}+12 \mathrm{D}+1 \mathrm{~F}+1 \mathrm{Dst}$ and the $\mathrm{n}$ female reduced gamete with $1 \mathrm{~A}+1 \mathrm{~B}+3 \mathrm{D}+4 \mathrm{E}$. In the same way, it was presumed that at least H15-701 was derived from the synapsis during the $2 \mathrm{n}$ male unreduced gamete including $1 \mathrm{~F}+1 \mathrm{Dst}$ and the $\mathrm{n}$ female reduced gamete including $1 \mathrm{~B}+7 \mathrm{E}$. However, the number of chromosomes and the karyotype compositions of the both parental gametes and the origin of the additional chromosomes were unclear because the additional chromosomes were caused by more abnormal meiosis. 




Figure 5. Identification of parental genome construction and unreduced gametes in the intergeneric hybrids between 'Kiyomi' tangor and Meiwa kumquat based on SSR genotyping in NSX43 (LG5) and CiBE2227 (LG8) loci.

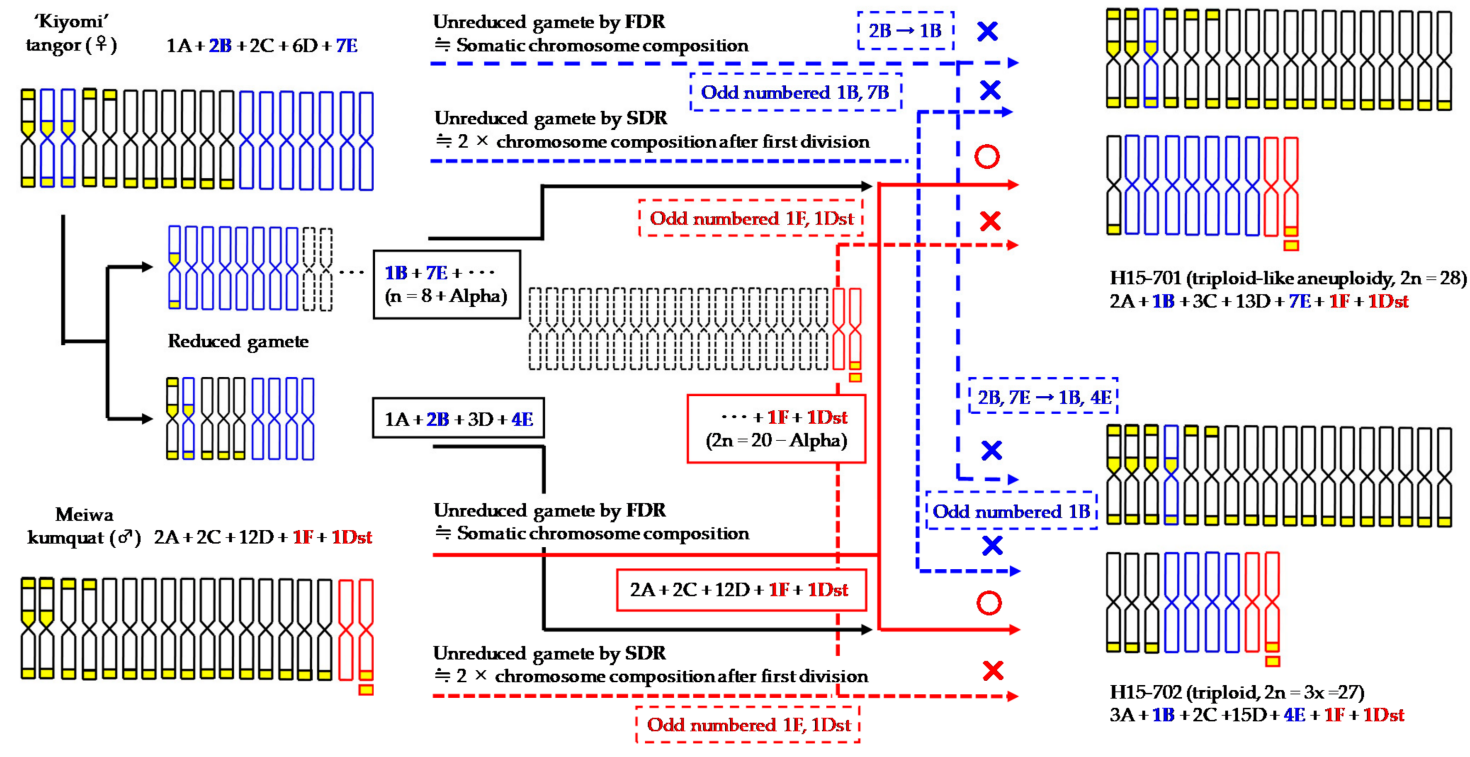

Figure 6. Identification of parental genome construction and unreduced gametes in the intergeneric hybrids between 'Kiyomi' tangor and Meiwa kumquat based on these CMA karyotype compositions.

\subsection{The Presence of Unreduced Male Gamete}

When we observed the pollen grains of Meiwa kumquat stained with acetocarmine under microscope, giant pollen grains were found at low frequency (Figure S1). The giant pollen was significantly larger than the normal pollen size $(27.3 \mu \mathrm{m}$ vs. $23.3 \mu \mathrm{m})$ and rather equivalent to the size $(27.0 \mu \mathrm{m})$ of the autotetraploid Meiwa kumquat (Table S2).

\subsection{The Morphological Characteristics and Fruit Traits Inherited by Hybrids}

H15-702 had an intermediate leaf size between the parents, while that of H15-701 was similar to that of Meiwa kumquat (Table 3, Figure 7). On the other hand, both intergeneric hybrids had significantly larger guard cells and significantly lower stomatal densities than the parents. Regarding the morphological characteristics of the flower, the lengths of the flower bud, petal, and pistil, and the width of the ovary in the hybrids were intermediate 
between the parents (Table 4, Figure 8). 'Kiyomi' tangor and Meiwa kumquat, respectively, have apical flower buds and apical-axillary flower buds, those of the intergeneric hybrids were acrogenous, and those of the hybrids were apical-axillary (data not shown). As for the morphological characteristics of the fruit, the fruit size, pericarp ratio, and the number of locules were intermediate between the parents, but the appearance of the fruit was rather similar to that of Meiwa kumquat (Table 5, Figure 9). The juice sac of Meiwa kumquat was undeveloped, unlike Citrus, but those of the intergeneric hybrids were relatively well developed. However, they were not fully developed to fill the segment, resulting in gaps of the flesh. Under conditions of open pollination, there were significantly fewer seeds in the fruits of the hybrids than in Meiwa kumquat. While 'Kiyomi' tangor and Meiwa kumquat were mono- and polyembryonic, H15-701 and H15-702 were poly- and monoembryonic, respectively. Soluble solid contents in the pericarps of the hybrids were significantly higher than those of the parents (Table 5).

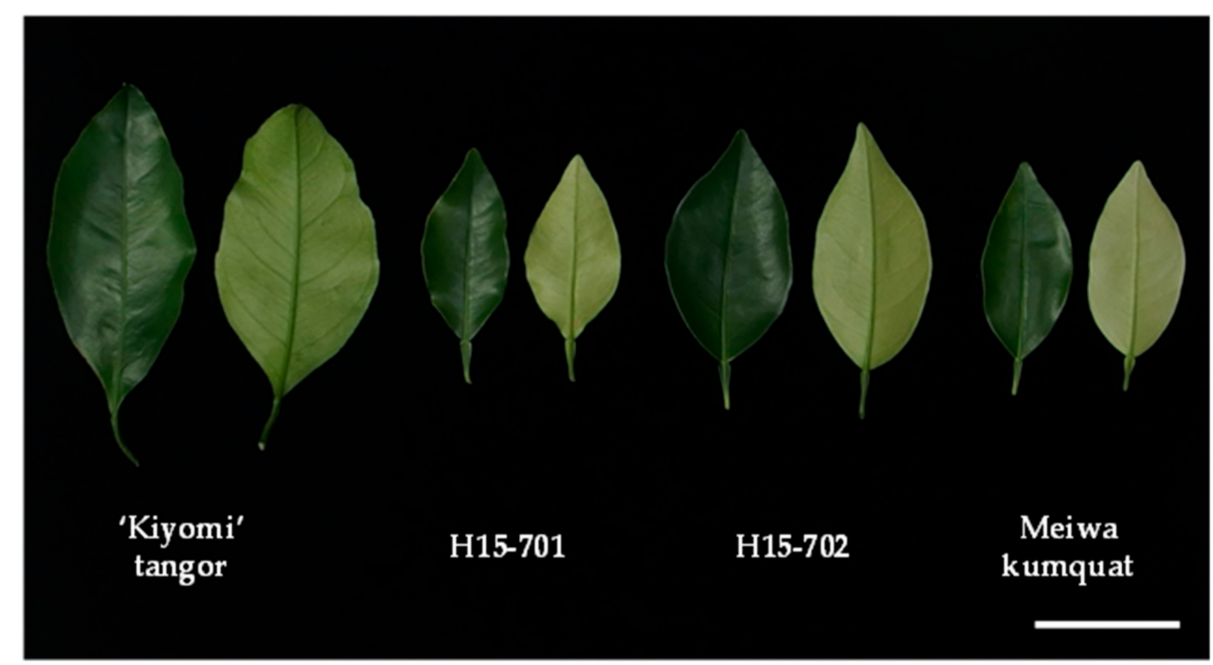

Figure 7. Comparison of morphological characteristics of leaves in 'Kiyomi' tangor, Meiwa kumquat, and their hybrids. $($ Bar $=5.0 \mathrm{~cm})$.
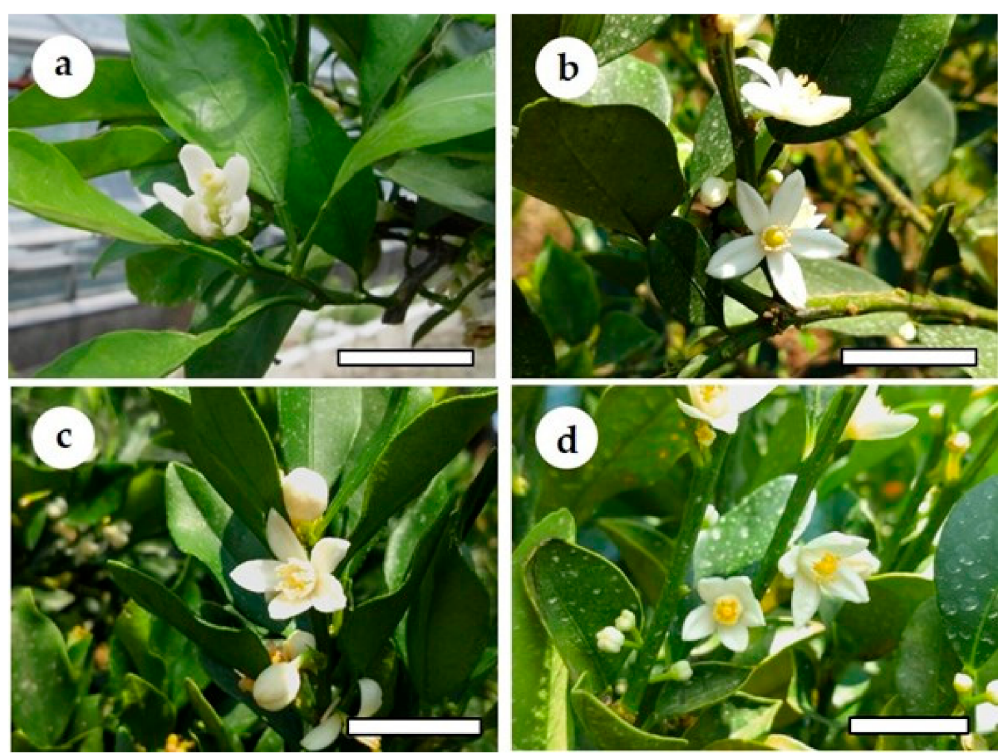

Figure 8. Comparison of morphological characteristics of flowers and flowering habits in 'Kiyomi' tangor, Meiwa kumquat, and their hybrids. (a) 'Kiyomi' tangor, (b) H15-701, (c) H15-702, (d) Meiwa kumquat. Bars $=2.0 \mathrm{~cm}$. 



$(\mathrm{n}=20)$.

\begin{tabular}{|c|c|c|c|c|c|c|c|c|c|c|c|}
\hline \multirow{2}{*}{ Strain } & \multirow{2}{*}{ Ploidy Level } & \multirow{2}{*}{$\begin{array}{c}\text { Leaf Area } \\
\left(\mathrm{cm}^{2}\right)\end{array}$} & \multicolumn{2}{|c|}{ Leaf Blade (mm) } & \multirow{2}{*}{$\begin{array}{l}\text { Shape Index of } \\
\text { Leaf Blade }^{1}\end{array}$} & \multicolumn{2}{|c|}{ Petiole Wing (mm) } & \multirow{2}{*}{$\begin{array}{l}\text { Shape Index of } \\
\text { Petiole Wing }{ }^{2}\end{array}$} & \multicolumn{2}{|c|}{ Guard Cell $(\mu \mathrm{m})$} & \multirow{2}{*}{$\begin{array}{l}\text { Stoma Density } \\
\left(\text { No. } \mathrm{mm}^{-2}\right)\end{array}$} \\
\hline & & & Length & Width & & Length & Width & & Length & Width & \\
\hline 'Kiyomi' tangor & $2 x$ & $39.9 \mathrm{a}$ & $104.0 \mathrm{a}$ & $51.3 \mathrm{a}$ & $203.5 \mathrm{~b}$ & $22.5 \mathrm{a}$ & $3.8 \mathrm{a}$ & $625.1 \mathrm{a}$ & $19.6 \mathrm{c}$ & $15.3 \mathrm{c}$ & $644.9 \mathrm{a}$ \\
\hline H15-701 & aneuploid $(2 \mathrm{n}=28)$ & $13.9 \mathrm{~d}$ & $60.2 c$ & $29.9 c$ & $201.8 \mathrm{bc}$ & $13.4 \mathrm{c}$ & $3.8 \mathrm{a}$ & $411.3 \mathrm{bc}$ & $24.7 \mathrm{a}$ & $22.1 \mathrm{a}$ & $323.6 \mathrm{c}$ \\
\hline $\mathrm{H} 15-702$ & $3 x$ & $27.9 \mathrm{~b}$ & $82.0 \mathrm{~b}$ & $44.2 \mathrm{~b}$ & $186.4 \mathrm{c}$ & $17.0 \mathrm{~b}$ & $3.8 \mathrm{a}$ & $356.9 \mathrm{c}$ & $23.4 \mathrm{~b}$ & $19.5 \mathrm{~b}$ & $333.3 \mathrm{c}$ \\
\hline Meiwa kumquat & $2 x$ & $17.0 \mathrm{c}$ & $70.0 \mathrm{c}$ & $29.8 \mathrm{c}$ & $236.8 \mathrm{a}$ & $11.5 \mathrm{c}$ & $2.8 \mathrm{~b}$ & $456.6 \mathrm{~b}$ & $19.7 \mathrm{c}$ & $16.2 \mathrm{c}$ & $431.6 \mathrm{~b}$ \\
\hline
\end{tabular}

${ }^{1}$ (Leaf blade length/leaf blade width) $\times 100{ }^{2}$ (Petiole wing length/petiole wing width) $\times 100$.

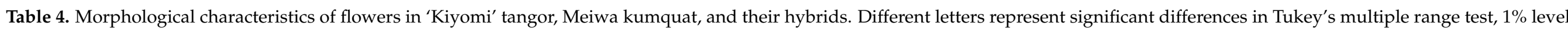
$(\mathrm{n}=20)$.

\begin{tabular}{|c|c|c|c|c|c|c|c|c|c|c|c|}
\hline \multirow{2}{*}{ Strain } & \multirow{2}{*}{ Ploidy Level } & \multicolumn{2}{|c|}{ Flower Bud (mm) } & \multirow{2}{*}{$\begin{array}{c}\text { Number of } \\
\text { Petal }\end{array}$} & \multicolumn{2}{|c|}{ Petal (mm) } & \multirow{2}{*}{$\begin{array}{c}\text { Number of } \\
\text { Pistil }\end{array}$} & \multirow{2}{*}{$\begin{array}{l}\text { Length of } \\
\text { Pistil (mm) }\end{array}$} & \multicolumn{2}{|c|}{ Ovary (mm) } & \multirow{2}{*}{$\begin{array}{l}\text { Number of } \\
\text { Stamen }\end{array}$} \\
\hline & & Length & Width & & Length & Width & & & Length & Width & \\
\hline 'Kiyomi' tangor & $2 x$ & $14.5 \mathrm{a}$ & $7.3 \mathrm{~b}$ & $4.6 \mathrm{~b}$ & $13.7 \mathrm{a}$ & $6.0 \mathrm{c}$ & $1.0 \mathrm{a}$ & $12.8 \mathrm{a}$ & $3.0 \mathrm{a}$ & $3.5 \mathrm{a}$ & $17.4 \mathrm{~b}$ \\
\hline H15-701 & aneuploid $(2 n=28)$ & $12.7 \mathrm{c}$ & $7.9 \mathrm{a}$ & $4.9 \mathrm{ab}$ & $12.3 \mathrm{~b}$ & $7.0 \mathrm{a}$ & $1.0 \mathrm{a}$ & $7.1 \mathrm{c}$ & $2.9 \mathrm{a}$ & $2.8 \mathrm{~b}$ & $17.5 \mathrm{~b}$ \\
\hline H15-702 & $3 x$ & $13.4 \mathrm{~b}$ & $7.2 \mathrm{~b}$ & $4.8 \mathrm{ab}$ & $12.9 \mathrm{~b}$ & $6.6 \mathrm{~b}$ & $1.0 \mathrm{a}$ & $7.6 \mathrm{~b}$ & $2.6 \mathrm{~b}$ & $2.3 c$ & $20.5 \mathrm{a}$ \\
\hline Meiwa kumquat & $2 x$ & $10.5 \mathrm{~d}$ & $6.2 c$ & $5.1 \mathrm{a}$ & $9.6 \mathrm{c}$ & $5.4 \mathrm{~d}$ & $1.0 \mathrm{a}$ & $5.6 \mathrm{~d}$ & $2.6 \mathrm{~b}$ & $2.1 \mathrm{~d}$ & $18.5 \mathrm{~b}$ \\
\hline
\end{tabular}

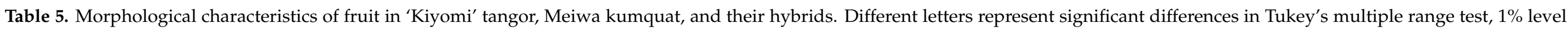
(number of embryos $=50$, others $=20$ ).

\begin{tabular}{|c|c|c|c|c|c|c|c|c|c|c|c|c|c|}
\hline \multirow{2}{*}{ Strain } & \multirow{2}{*}{$\begin{array}{c}\text { Ploidy } \\
\text { Level }\end{array}$} & \multirow{2}{*}{$\begin{array}{c}\text { Fruit } \\
\text { Weight (g) }\end{array}$} & \multicolumn{2}{|c|}{ Fruit (mm) } & \multirow{2}{*}{$\begin{array}{l}\text { Shape Index } \\
\text { of Fruit }{ }^{1}\end{array}$} & \multirow{2}{*}{$\begin{array}{l}\text { Thickness of } \\
\text { Pericarp (mm) }\end{array}$} & \multirow{2}{*}{$\begin{array}{c}\text { Rate of } \\
\text { Pericarp (\%) }\end{array}$} & \multirow{2}{*}{$\begin{array}{l}\text { Number of } \\
\text { Locule }\end{array}$} & \multicolumn{2}{|c|}{ Number of Seed per Fruit } & \multirow{2}{*}{$\begin{array}{c}\text { Number of } \\
\text { Embryo per } \\
\text { Seed }\end{array}$} & \multicolumn{2}{|c|}{$\operatorname{SSC}^{4}\left({ }^{\circ}\right.$ Brix $)$} \\
\hline & & & Diameter & Height & & & & & Depeloped & Undeveloped $^{3}$ & & Pericarp & Juice sac \\
\hline $\begin{array}{l}\text { 'Kiyomi' } \\
\text { tangor }\end{array}$ & $2 x$ & $256.5 \mathrm{a}$ & 79.9 a & $75.0 \mathrm{a}$ & $106.4 \mathrm{a}$ & $5.1 \mathrm{a}$ & $12.7 \mathrm{~d}$ & $12.0 \mathrm{a}$ & $0 \mathrm{c}$ & $0 \mathrm{~b}$ & - & $15.1 \mathrm{~d}$ & $11.1 \mathrm{c}$ \\
\hline H15-702 & $3 x$ & $28.9 \mathrm{~b}$ & $35.1 \mathrm{c}$ & $41.3 \mathrm{~b}$ & $85.2 \mathrm{c}$ & $4.4 \mathrm{~b}$ & $25.0 \mathrm{~b}$ & $7.4 \mathrm{~b}$ & $0.4 \mathrm{c}$ & $0.6 \mathrm{ab}$ & $1.1 \mathrm{c}$ & $24.3 \mathrm{a}$ & $12.9 \mathrm{~b}$ \\
\hline $\begin{array}{l}\text { Meiwa } \\
\text { kumquat }\end{array}$ & $2 x$ & $14.7 \mathrm{~b}$ & $28.6 \mathrm{~d}$ & $30.9 \mathrm{~d}$ & $92.6 \mathrm{~b}$ & $4.1 \mathrm{c}$ & $28.5 \mathrm{a}$ & $6.5 \mathrm{c}$ & $7.3 \mathrm{a}$ & $0.7 \mathrm{a}$ & $6.9 \mathrm{a}$ & $22.0 \mathrm{c}$ & $15.8 \mathrm{a}$ \\
\hline
\end{tabular}

${ }^{1}$ (Diameter $/$ height) $\times 100 ;{ }^{2}$ (thickness of pericarp $/$ radius of fruit) $\times 100 ;{ }^{3}$ empty seeds; ${ }^{4}$ soluble solid content. 


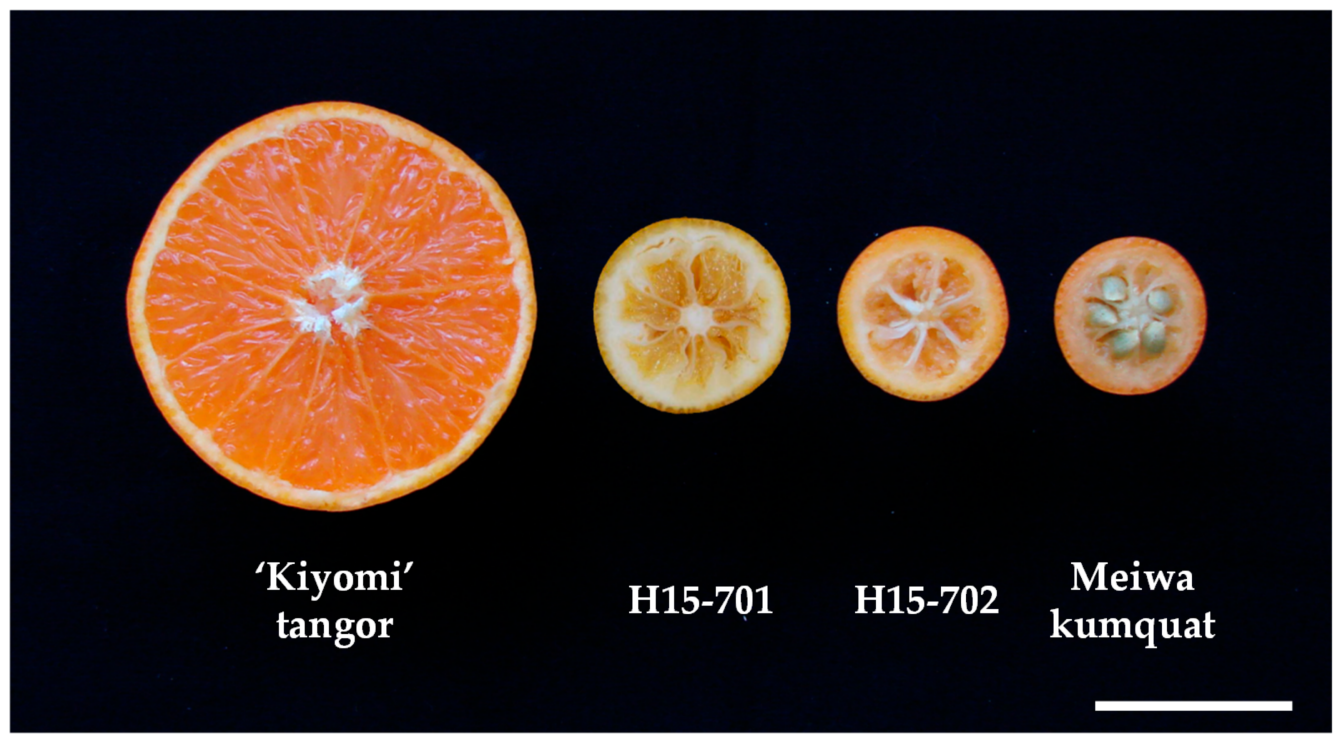

Figure 9. Comparison of morphological characteristics of fruits in 'Kiyomi' tangor, Meiwa kumquat, and their hybrids by cross section of mature fruits. Bar $=5.0 \mathrm{~cm}$.

\section{Discussion}

From the GISH analysis, we could not obtain the desired result due to the mishybridization of the 'Kiyomi' tangor DNA probe to the chromosomes derived from Meiwa kumquat in the intergeneric hybrids between Citrus and Fortunella, indicating that these two genera have a high genetic homology.

In this study, genotyping was possible with PAGE, which did not require expensive primers or analytical equipment. The detected 'Kiyomi' tangor- and Meiwa kumquatspecific alleles were powerful tools for identifying the parental genomes of the intergeneric hybrids and for clarifying the process of polyploidization. Although only two SSR loci were analyzed in this study, it was thought that more detailed inheritance would be clarified by using more markers and their neighboring markers in the future. The CMA karyotype composition of 'Kiyomi' tangor was revealed as $1 \mathrm{~B}+2 \mathrm{C}+7 \mathrm{D}+8 \mathrm{E}$ in a previous study [39], but our present results show $1 \mathrm{~A}+2 \mathrm{~B}+2 \mathrm{C}+6 \mathrm{D}+7 \mathrm{E}$ with different numbers of types $\mathrm{A}$, $\mathrm{B}, \mathrm{D}$, and E. Guerra [40] classified more specifically the chromosomes with one telomeric band into three karyotypes based on the size of the CMA-positive signal. In contrast, we simply classified these into only type $\mathrm{D}$ because the signal sizes depended on the degree of chromosome condensation or the judgment of the observer; therefore, these four karyotypes might be confused with chromosomes with or without a delicate telomeric band. We previously explained the difference from the karyotype composition without types F and Dst of Meiwa kumquat reported by Miranda et al. [24,41]. The presence of types B and E as maternal-specific karyotypes and of types F and Dst as paternal-specific karyotypes were very useful for confirming the parental genome construction of hybrids.

As for the results of the estimation based on CMA karyotype compositions, we concluded that the hybrids of both H15-701 and H15-702 might each have two genomes of Meiwa kumquat derived from the $2 \mathrm{n}$ male unreduced gamete by FDR. The polyploidization through sexual crosses in citrus has been attributed in many studies to the occurrence of the 2n female unreduced gamete [42-45]. That proposition was strongly confirmed by detailed genetic analyses with molecular markers, and then it was reported recently that most of the $2 \mathrm{n}$ female unreduced gametes were formed by SDR with the maximum-likelihood method based on parental heterozygosity restitution (PHR) [3,13,14,46,47]. In contrast. Yang et al. [16] described that the triploid progenies from diploid-diploid crosses in pummelo could be due to either the $2 \mathrm{n}$ male or $2 \mathrm{n}$ female unreduced gamete based on these CMA karyotype compositions. The recent study revealed that 'Nishiuchi Konatsu' as a bud-mutated cultivar of hyuga-natsu (C. tamurana hort. ex Tanaka) produced the giant 
pollen derived from the $2 \mathrm{n}$ male unreduced gamete by FDR with the single-pollen genotyping method using SSR molecular markers and heterozygous transmission analysis $[48,49]$. Moreover, Rouiss et al. [15] proved the existence of the $2 \mathrm{n}$ male unreduced gamete by both FDR and SDR with the maximum-likelihood method based on PHR in tetraploid hybrids from tetraploid-diploid crosses. Our present results also supported that the $2 n$ male unreduced gamete by FDR was related to polyploidization in sexual crosses of citrus. In addition, we not only demonstrated the existence of the $2 \mathrm{n}$ male unreduced gamete by estimation based on CMA karyotype compositions, but the presence of giant pollen was actually observed in Meiwa kumquat as a male parent. It is generically known that giant pollen appears as a product of the $2 \mathrm{n}$ pollen in many fruits [50-52]. In the same way, the $2 \mathrm{n}$ pollen of autotetraploid has a 1.3-fold greater diameter than that of the $n$ pollen of diploid in Citrus [53]. The giant pollen in this study was slightly smaller than 1.3-fold the normal pollen size in diploid Meiwa kumquat, but that size was equivalent to that of autotetraploid Meiwa kumquat. This supported our estimation of the parental genome construction and the polyploidization process, including the existence of the $2 \mathrm{n}$ male unreduced gamete.

Most of the morphological characteristics of the leaves, flowers, and fruits of both hybrids showed intermediate traits of the parents, but the fruit sizes and flowering habits were more like those of the Meiwa kumquat. Although morphological characteristics are generally quantitative traits, their similarities to Meiwa kumquat might be derived from the 1:2 genomic ratio of 'Kiyomi' tangor to Meiwa kumquat. The larger size of guard cells and lower stomatal density observed in hybrids are general features of a polyploid. In Meiwa kumquat, it was reported that the tetraploid and $2 x+4 x$ chimera had higher soluble solid contents than the diploid wild type [54-56]. Therefore, the present result of the higher soluble solid accumulation into pericarp than the parents might be due to triploidy. Both hybrids were expected to be dominant polyembryonic because they inherited almost all genes by FDR. However, H15-702 was monoembryonic, so a detailed genetic analysis would be required in the future.

\section{Conclusions}

In conclusion, while GISH analysis, though a powerful tool for this purpose, failed due to the high genomic homology between the male and female parents, we successfully identified the parental genome construction of the triploid and aneuploid intergeneric hybrids based on the integrated results of SSR genotyping and CMA analysis. It showed that these hybrids might have two genomes derived from the $2 \mathrm{n}$ male unreduced gamete by FDR of Meiwa kumquat. The morphological characteristics of these hybrids resembled Meiwa kumquat with two genomes inherited.

Supplementary Materials: The following are available online at https:/ /www.mdpi.com/article/ 10.3390/agronomy11101988/s1, Figure S1: Appearance of the giant pollen in the acetocarminestained pollens of Meiwa kumquat, Table S1: Information on SSR markers used in this study with their GenBank accession numbers, linkage groups, primer sequences, repeat motifs, bibliographic references, and optimal annealing temperatures, Table S2: Comparison of pollen size between the normal or giant pollens in diploid and autotetraploid Meiwa kumquat.

Author Contributions: Conceptualization, K.Y., M.Y. and H.K.; methodology, K.Y.; formal analysis, K.Y., M.Y. and A.T.; investigation, K.Y., M.Y., M.S. (Mai Sato), M.S. (Miki Sudo) and A.T.; resources, K.Y., M.Y., M.S. (Miki Sudo) and H.K.; data curation, K.Y., M.Y., M.S. (Mai Sato), M.S. (Miki Sudo) and A.T.; writing-original draft preparation, K.Y.; writing—review and editing, K.Y., M.Y. and H.K.; visualization, K.Y.; supervision, H.K.; project administration, H.K.; funding acquisition, H.K. All authors have read and agreed to the published version of the manuscript.

Funding: This research was funded by Grant-in-Aid for Scientific Research (C), grant number JP20K06020. The APC was funded by Grant-in-Aid for Scientific Research (C), grant number JP20K06020.

Institutional Review Board Statement: Not applicable.

Informed Consent Statement: Not applicable. 
Acknowledgments: We would like thank Minoru Fukada, representative director of Yoshiokakokkoen Co., Ltd. (Fukuoka, Japan) for propagating plant materials by grafting and providing their goodquality nursery plants.

Conflicts of Interest: The authors declare no conflict of interest.

\section{References}

1. Swingle, W.T.; Reece, P.C. The botany of Citrus and its wild relatives in the orange subfamily. In The Citrus Industry; Reuther, W., Webber, H.J., Bachelor, L.D., Eds.; University of California: Berkley, CA, USA, 1967; Volume I, pp. $190-430$.

2. Yasuda, K.; Yahata, M.; Komatsu, K.; Kurogi, Y.; Kunitake, H. Triploid and aneuploid hybrids from diploid-diploid intergeneric crosses between Citrus cultivar 'Kiyomi' tangor and Meiwa kumquat (Fortunella crassifolia Swingle) for seedless breeding of kumquat. J. Jpn. Soc. Hortic. Sci. 2010, 79, 16-22. [CrossRef]

3. Aleza, P.; Juarez, J.; Cuenca, J.; Ollitraut, P.; Navarro, L. Recovery of citrus triploid hybrids by embryo rescue and flow cytometry from $2 x \times 2 x$ sexual hybridization and its application to extensive breeding programs. Plant Cell Rept. 2010, 29, 1573-1586. [CrossRef]

4. Esen, A.; Soost, R.K. Unexpected triploid in Citrus: Their origin, identification and possible use. J. Hered. 1971, 62, 329-333. [CrossRef]

5. Lapin, W.K. Investigation of polyploidy in citrus. USSR All-Union Sci. Res. Inst. Humid Subtrop. Works 1937, 1, 1-68.

6. Navarro, L.; Aleza, P.; Cuence, J.; Juarez, J.; Pina, J.A.; Ortega, C.; Navarro, A.; Ortega, V. The mandarin triploid breeding program in Spain. Acta Hortic. 2015, 1065, 389-396. [CrossRef]

7. Ollitraut, P.; Damber, D.; Luro, F.; Froelicher, Y. Ploidy manipulation for breeding seedless triploid citrus. Plant Breed. Rev. 2008, 30, 323-352.

8. Toolapong, P.; Komatsu, H.; Iwamasa, M. Triploids and haploid progenies derived from small seeds of 'Banpeiyu' pummelo, crossed with 'Ruby Red' grapefruits. J. Jpn. Soc. Hortic. Sci. 1996, 65, 255-260. [CrossRef]

9. Yang, X.; Kitajima, A.; Behu, M.; Hasegawa, K. Variation in chromosome number of hybrid seedlings between 'Tosa-Buntan' and 'Suisho-Buntan' pummelo (Citrus grandis [L.] Osb.). J. Jpn. Soc. Hortic. Sci. 2000, 69, 308-314, (In Japanese with English abstract). [CrossRef]

10. De Stome, N.; Geelen, D. Sexual polyploidization in plants-cytological mechanism and molecular regulation. New Phytol. 2013, 198, 670-684. [CrossRef]

11. Mendiburu, A.O.; Peloquin, S.J. Sexual polyploidization and depolyploidization, some terminology and definitions. Theor. Appl. Genet. 1976, 48, 137-143. [CrossRef]

12. Chen, C.; Lyon, M.T.; O’Malley, D.; Federici, C.T.; Gmitter, J.; Grosser, J.W.; Chaparro, J.X.; Roose, M.L.; Gmitter, F.G., Jr. Origin and frequency of $2 \mathrm{n}$ gametes in Citrus sinensis $\times$ Poncirus trifoliata and their reciprocal crosses. Plant Sci. 2008, 174, 1-8. [CrossRef]

13. Cuenca, J.; Aleza, P.; Juarez, J.; Garcia-Lor, A.; Froelicher, Y.; Navarro, L.; Ollitrault, P. Maximum-likelihood method identifies meiotic restitution mechanism from heterozygosity transmission of centromeric loci: Application in citrus. Sci. Rep. 2015, 5, 9897. [CrossRef]

14. Rouiss, H.; Cuenca, J.; Navarro, L.; Ollitrault, P.; Aleza, P. Unreduced megametophyte production in lemon occurs via three meiotic mechanisms, predominantly second-division restitution. Front. Plant Sci. 2017, 8, 1211. [CrossRef]

15. Rouiss, H.; Cuenca, J.; Navarro, L.; Ollitrault, P.; Alez, P. Tetraploid citrus progenies arising from FDR and SDR unreduced pollen in $4 \mathrm{x} \times 2 \mathrm{x}$ hybridizations. Tree Genet. Genomes 2017, 13, 10. [CrossRef]

16. Yang, X.; Kitajima, A.; Hasegawa, K. Chromosome pairing set and the presence of unreduced gametes explain the possible orgin of polyploidy progenies from the diploids 'Tosa-Buntan' $\times$ 'Suisho-Buntan' pumelo. J. Jpn. Soc. Hortic. Sci. 2002, 71, 538-543, (In Japanese with English abstract). [CrossRef]

17. Befu, M.; Kitajima, A.; Ling, Y.X.; Hasegawa, K. Classification of 'Tosa-Buntan' pummelo (Citrus grandis [L.] Osb.), 'Washington' navel orange (C. sinensis [L.] Osb.) and trifoliate orange (Poncirus trifoliate [L.] Raf.) chromosomes using young leaves. J. Japan. Soc. Hort. Sci. 2000, 69, 22-28. [CrossRef]

18. Cornelio, M.T.M.N.; Figueiroa, A.R.S.; Santos, K.G.B.; Carvalho, R.; Soares Filho, W.S.; Guerra, M. Chromosomal relationships among cultivars of Citrus reticulata Blanco, its hybrids and related species. Plant Syst. Evol. 2003, 240, 149-161. [CrossRef]

19. Moraes, A.P.; Soares Filho, W.S.; Guerra, M. Karyotype diversity and origin of grapefruits. Chromosome Res. 2007, 15, 115-121. [CrossRef] [PubMed]

20. Nukaya, T.; Ohta, T.; Yasuda, K.; Yahata, M.; Kunitake, H.; Komatsu, H.; Nii, N.; Mukai, H.; Harada, H.; Takagi, T. Characteristics in polyploid Meiwa kumquat (Fortunella crassifolia Swingle) induced by colchicine treatment to nucellar embryos and their utilization for triploid breeding. Hort. Res. 2011, 10, 1-8, (In Japanese with English abstract). [CrossRef]

21. Yahata, M.; Kunitake, H.; Yabuya, T.; Yamashita, K.; Kashihara, Y.; Komatsu, H. Production of a doubled haploid from a haploid pummelo using colchicine treatment of axillary shoot buds. J. Am. Soc. Hortic. Sci. 2005, 130, 899-903. [CrossRef]

22. Yamamoto, M. Application of fluorescent staining of chromosomes to genetic studied in citrus. J. Jpn. Soc. Hortic. Sci. 2007, 1, 12-19.

23. Yamamoto, M.; Abkenar, A.A.; Matsumoto, R.; Kubo, T.; Tominaga, S. CMA staining analysis of chromosomes in several species of Aurantioideae. Genet. Resour. Crop Evol. 2008, 55, 1167-1173. [CrossRef] 
24. Yasuda, K.; Yahata, M.; Kunitake, H. Phylogeny and classification of kumquat (Fortunella spp.) inferred from CMA karyotype composition. Hortic. J. 2016, 85, 115-121. [CrossRef]

25. Raina, S.N.; Rani, V. GISH technology in plant genome research. Methods Cell Sci. 2001, 23, 83-104. [CrossRef] [PubMed]

26. Fu, C.H.; Chen, C.L.; Guo, W.W.; Deng, X.X. GISH, AFLP and PCR-RFLP analysis of an intergeneric somatic hybrid combining Goutou sour orange and Poncirus trifoliaata. Plant Cell Rept. 2004, 23, 391-396. [CrossRef]

27. Yasuda, K.; Yahata, M.; Shigyo, M.; Matsumoto, R.; Yabuya, T.; Kunitake, H. Identification of parental chromosomes in sexual intergeneric hybrid progenies between Citrus cultivar 'Nanpu' tangor and Citropsis schweinfurthii in the subfamily Aurantioideae. J. Jpn. Soc. Hortic. Sci. 2010, 79, 129-134. [CrossRef]

28. Karlov, G.I.; Khrustaleva, L.I.; Lim, K.B.; van Tuyl, J.M. Homoelogous recombination in 2n-gametes producing interspecific hybrids of Lilium (Liliaceae) studied by genomic in situ hybridization (GISH). Genome 1999, 42, 681-686. [CrossRef]

29. Lim, K.B.; Ramanna, M.S.; de Jong, J.H.; Jacobsen, E.; van Tuyl, J.M. Indeterminate meiotic restitution (IMR): A novel type of meiotic nuclear restitution mechanism detected in interspecific lily hybrids by GISH. Theor. Appl. Genet. 2001, 103, 219-230. [CrossRef]

30. Ramanna, M.S.; Kuipers, A.G.J.; Jacobsen, E. Occurrence of numerically unreduced (2n) gametes in Alstroemeria interspecific hybrids and their significance for sexual polyploidisation. Euphytica 2003, 133, 95-106. [CrossRef]

31. Doyle, J.; Doyle, J.L. A rapid DNA isolation procedure for small quantities fresh leaf tissue. Phytochem. Bull. 1987, $19,11-15$.

32. Ollitraut, F.; Terol, J.; Pina, J.A.; Navarro, L.; Talon, M.; Ollitraut, P. Development of SSR markers from Citrus clementina (Rutaceae) BAC end sequences and interspecific transferability in Citrus. Am. J. Bot. 2010, 97, e124-e129. [CrossRef] [PubMed]

33. Ollitraut, P.; Terol, J.; Chen, C.; Federici, C.T.; Lotfy, S.; Hippolyte, I.; Ollitraut, F.; Berard, A.; Chauveau, A.; Cuenca, J.; et al. A reference genetic map of C. clementina hort. ex Tan.; citrus evolution inferences from comparative mapping. BMC Genom. 2012, 13,592 .

34. Shimizu, T.; Kitajima, A.; Nonaka, K.; Yoshioka, T.; Ohta, S.; Goto, S.; Toyoda, A.; Fujiyama, A.; Mochizuki, T.; Nagasaki, H.; et al. Hybrid origins of citrus varieties inferred from DNA marker analysis of nuclear and organelle genomes. PLoS ONE 2016, 11, e0166969. [CrossRef]

35. Fukui, K. Plant chromosome at mitosis. In Plant Chromosome. Laboratry Methods; Fukui, K., Nakayama, S., Eds.; CRC Press: Boca Raton, Fl, USA, 1996; pp. 1-17.

36. Yahata, M.; Nukaya, T.; Sudo, M.; Ohta, T.; Yasuda, K.; Inagaki, H.; Mukai, H.; Harada, H.; Takagi, T.; Komatsu, H.; et al. Morphological characteristics of a doubled haploid line from 'Banpeiyu' pumelo [Citrus maxima (Burm.) Merr.] and its reproductive function. Hortic. J. 2015, 84, 30-36. [CrossRef]

37. Kawase, K.; Yahata, M.; Nakagawa, S.; Haraguchi, K.; Kunitake, H. Selection of autotetraploid and its morphological characteristics in Meiwa kumquat (Fortunella crassifolia Swingle). Hortic. Res. 2005, 4, 141-146, (In Japanese with English abstract). [CrossRef]

38. Yamamoto, M.; Tominaga, S. High chromosomal variability of mandarins (Citrus spp.) revealed by CMA banding. Euphytica 2003, 129, 267-274. [CrossRef]

39. Yahata, M.; Kurogi, H.; Kunitake, H.; Nagano, K.; Yabuya, T.; Yamashita, K.; Komatsu, H. Evaluation of reproductive function in a haploid pummelo by crossing with several diploid citrus cultivars. J. Jpn. Soc. Hortic. Sci. 2005, 74, 281-288. [CrossRef]

40. Guerra, M. Cytogenetics of Rutaceae. V. high chromosomal variability in Citrus species revealed by CMA/DAPI staining. Heredity 1993, 71, 234-241. [CrossRef]

41. Miranda, M.; Ikeda, F.; Endo, T.; Moriguchi, T.; Omura, M. Comparative analysis on the distribution of heterochromatin in Citrus, Poncirus and Fortunella chromosomes. Chromosome Res. 1997, 5, 86-92. [CrossRef]

42. Esen, A.; Soost, R.K. Tetraploids progenies from $2 x \times 4 x$ crosses and their origin. J. Am. Soc. Hortic. Sci. 1972, 97, $410-414$.

43. Esen, A.; Soost, R.K. Seed development in citrus with special reference to $2 x \times 4 x$ crosses. Am. J. Bot. 1973, 60, 448-462. [CrossRef]

44. Esen, A.; Soost, R.K.; Geraci, G. Seed set, size and development after $4 x \times 2 x$ and $4 x \times 4 x$ crosses in citrus. Euphytica 1978, 27, 283-294. [CrossRef]

45. Esen, A.; Soost, R.K.; Geraci, G. Genetic evidence for the origin of diploid megagametophytes in Citrus. J. Hered. 1979, 70, 5-8. [CrossRef]

46. Cuenca, J.; Froelicher, Y.; Aleza, P.; Juarez, J.; Navarro, L.; Ollitraut, P. Multilocus half-tetrad analysis and centromere mapping in citrus: Evidence of SDR mechanism for $2 \mathrm{n}$ megagametophyte production and partial chiasma interference in mandarin $\mathrm{cv}$ 'Fortune'. Heredity 2011, 107, 462-470. [CrossRef]

47. Luro, F.; Maddy, F.; Jacquemond, C.; Froelicher, Y.; Morillon, R.; Rist, D.; Ollitraut, P. Identification and evaluation of diplogyny in clementine (Citrus clementina) for use in breeding. Acta Hortic. 2004, 663, 841-848. [CrossRef]

48. Honsho, C.; Yamamura, E.; Tsuruta, K.; Toshimura, Y.; Yasuda, K.; Uchida, A.; Kunitake, H.; Tetsumura, T. Unreduced 2n pollen production in 'Nishiuchi Konatsu' Hyuganatsu as inferred by pollen characteristics and progeny ploidy level. J. Jpn. Soc. Hortic. Sci. 2012, 81, 19-26. [CrossRef]

49. Honsho, C.; Sakata, A.; Tanaka, H.; Ishimura, S.; Tetsumura, T. Single-pollen genotyping to estimate mode of unreduced pollen formation in Citrus tamurana cv. Nishiuchi Konatsu. Plant Reprod. 2016, 29, 189-197. [CrossRef] [PubMed]

50. Dermen, H. Detection of polyploidy by pollen-grain size. I. Investigations with peaches and apricots. J. Am. Soc. Hortic. Sci. 1937, 35, 96-103.

51. Maertens, M.H.R.; Reisch, B.I.; Mauro, M.C. Pollen size variability within genotypes of Vitis. HortScience 1989, $24,659-662$. 
52. Yamada, A.; Tao, R.; Sugiura, A. Influence of low temperature before flowering on the occurrence of unreduced pollen in Japanese persimmon (Diospyros kaki Thunb.). HortScience 2005, 40, 24-28. [CrossRef]

53. Oiyama, I. Studies on polyploidy breeding in Citrus with special reference to the production of tetraploid breeding. Bull. Fruit Tree Res. Stn. 1992, 3, 1-68, (In Japanese with English abstract).

54. Nukaya, T.; Sudo, M.; Yahata, M.; Nakajyo, Y.; Ohta, T.; Yasuda, K.; Tominaga, A.; Mukai, H.; Kunitake, H. Characteristics in autotetraploid kumquats (Fortunella spp.) induced by colchicine treatment to nucellar embryos and their utilization for triploid breeding. Scientia 2019, 245, 210-217. [CrossRef]

55. Nukaya, T.; Sudo, M.; Yahata, M.; Ohta, T.; Tominaga, A.; Mukai, H.; Yasuda, K.; Kunitake, H. The confirmation of a ploidy periclinal chimera of the Meiwa kumquat (Fortunella crassifolia Swingle) induced by colchicine treatment to nucellar embryos and its morphological characteristics. Agronomy 2019, 9, 562. [CrossRef]

56. Yasuda, K.; Kunitake, H.; Nakagawa, S.; Kurogi, H.; Yahata, M.; Hirata, R.; Yoshikura, Y.; Kawakami, I.; Sugimoto, Y. The confirmation of ploidy periclinal chimera and its morphological characteristics in Meiwa kumquat 'Yubeni'. Hortic. Res. 2008, 7, 165-171. (In Japanese with English abstract) [CrossRef] 